\title{
Association of RYR1 and MYOG Genotype with Carcass and Meat Quality Traits in Grower-finisher Pigs
}

\author{
Artur Rybarczyk ${ }^{1}$, Arkadiusz Pietruszka², Eugenia Jacyno², Josef Dvořák ${ }^{3}$, \\ Tadeusz Karamucki ${ }^{1}$, Małgorzata Jakubowska ${ }^{1}$ \\ ${ }^{1}$ Department of Livestock Product Evaluation and ${ }^{2}$ Department of Pig Breeding, University of Agriculture \\ in Szczecin, Szczecin, Poland \\ ${ }^{3}$ Department of Genetics, Mendel University of Agriculture and Forestry, Brno, Czech Republic
}

Received August 28, 2008

Accepted October 21, 2009

\begin{abstract}
The study involved 110 hybrid grower-finisher pigs from Polish Large White $\times$ Polish Landrace sows sired by Pietrain breed boars and their crossbreds with the 990 line and Duroc. The aim of the study was to determine an association of the polymorphism of $R Y R l$, myogenin $(M Y O G)$ genes and carcass meatiness level with carcass slaughter value and meat quality traits in hybrid pigs. Better meat quality was found in pigs of $C C$ genotype at locus $R Y R I$ than in those of $C T$ genotype, with a similar carcass slaughter value and meat chemical composition. No significant differences were found in meat traits (carcass slaughter value) and quality between $A A$ and $A B$ genotypes at locus $M Y O G$. Similarly, no significant differences were found between carcass meatiness ranges adopted in meat quality and its chemical composition, except for water holding capacity, which was higher in pigs with $\leq 54 \%$ meatiness than in those with $>54 \%$. Moreover, interaction was found between carcass meatiness range and $R Y R l$ genotype in relation to backfat thickness and intramuscular fat content, as well as a connection between carcass meatiness range and $M Y O G$ genotype in relation to water-soluble protein content. The results indicate the need to continue selection work towards the elimination of allele $T$ RYR1 gene's in pedigree herds to improve meat quality in fatteners.
\end{abstract}

Grower-finisher pigs, myogenin, RYR1, meatiness, meat quality

Studies indicate that pigs belonging to different breeds but characterised by the same genotype at the RYRl locus show significant differences in carcass meatiness and meat quality. The occurrence of PSE meat among pigs of $C C$ genotype or the occurrence of normal meat in animals of TT genotype may be a consequence of the effect of other genes on carcass and meat quality traits modifying the effect of $R Y R 1$ genotype (Koćwin-Podsiadła and Kurył 2003). It has been found that some other genes or their families could be singled out as so-called candidate genes with a potential effect on carcass meatiness based on their participation in the processes of skeletal muscle development in the foetal period. These genes include the MyoD family genes, i.e. MYOD1 (MYF3), MYF5, MYOG (MYF4) and MYF6 (MRF4) (Te Pas and Visscher 1994). It has been shown that significance of the relationship between the value of some carcass traits and $M Y O G$ genotype was breeddependent (Kurył et al. 2002; Cieślak et al. 2002). Studies of the aforementioned authors and those of Krzęcio et al. (2007a) showed that MYOG genotype was associated with the formation of selected carcass quality traits, whereas those of Kapelański et al. (2005) and Krzęcio et al. (2007b) also pointed to a link with pork quality. On the other hand, Urbański et al. (2007) did not find significant relationships between MYOG genotype and the structure of porcine longissimus dorsi muscle. Moreover, Horák et al. (2004) showed an association between $M Y O G$ gene polymorphism and reproductive traits in Přeštice Black-Pied breed pigs.

This study was aimed at determining an association of the polymorphism of RYRl, 
myogenin $(M Y O G)$ and carcass meatiness level genes with carcass slaughter value and meat quality traits in hybrid grower-finisher pigs.

\section{Materials and Methods}

The study was carried out on 110 hybrid grower-finisher pigs, including 57 barrows and 53 gilts, from Polish Large White $\times$ Polish Landrace sows sired by Pietrain boars and their crossbreds with 990 line and Duroc. The animals were individually kept and fed at a pig farm at the Experimental Station of Animal Production (National Research Institute of Animal Production) in Kołbacz, Poland. The energy value and basic chemical composition of feed mixture used in the study was consistent with the Pig Nutrition Standards of 1993.

After reaching the body weight of $100 \pm 2 \mathrm{~kg}$, the pigs were slaughtered and blood samples were collected for DNA analysis to identify all genotypes at loci $R Y R I$ and $M Y O G$. During slaughter operation, meat acidity $\left(\mathrm{pH}_{1}\right)$ was measured $45 \mathrm{~min}$ after bleeding ( $\mathrm{pH}$-meter CP-311, Elmetron) in the longissimus dorsi (LD) muscle between the $4^{\text {th }}$ and the $5^{\text {th }}$ lumbar vertebrae of the right half-carcass; warm carcass weight was also determined. The mean carcass weight was $81.02 \pm 1.33 \mathrm{~kg}$. Thereafter, following a 24-hour chilling, the carcasses were dissected according to the methods used at Swine Testing Stations (Różycki 1996) and the meat $\mathrm{pH}_{24}$ was determined. The dissection results were then used for the calculation of the carcass lean content. Hybrid porker carcasses were divided into two groups according to their meatiness: $\mathrm{I} \leq 54 \%(\mathrm{n}=61)$ and II $>54 \%(\mathrm{n}=49)$. During cutting, meat samples were collected from the LD muscle from the lumbar vertebrae 1-4 section of the right half-carcass. Approximately $48 \mathrm{~h}$ after slaughter, $\mathrm{pH}$ measurement was done in water solution on mixed and diluted muscle tissue, meat colour lightness ( $\mathrm{L}^{*}$ ) was determined by means of HunterLab Mini Scan XE 45/0 apparatus (CIE 1976), water holding capacity was determined by the Grau-Hamma method as modified by Pohja and Niinivaara (1957), thermal drip according to Walczak (1959), water-soluble protein content by Kotik's method (1974), as well as the assay of meat basic chemical composition, i.e. total protein, fat, ash, and dry matter (AOAC 1990). Examination of the tenderness of the longissimus dorsi muscle (last four thoracic vertebrae) was performed by means of an Instron 1140 Universal Testing Machine (Instron, High Wycombe, UK) using the Warner-Bratzler test. The DNA analysis, by PCR/RFLP technique, was performed at the Institute of Genetics of the Mendel University of Agriculture and Forestry in Brno, Czech Republic. The RYR1 genotypes were identified by means of $\mathrm{HinPI}$ endonuclease (Fujii et al. 1991), whereas the polymorphism of MYOG gene by means of the restriction enzyme $M s p I$ in the 3' region (Soumillion et al. 1997).

The statistical analysis was performed to compare carcass and meat quality traits and meat basic chemical composition between pigs of different RYRI and MYOG genotypes and meatiness group, using the least squares method of the GLM procedure (Statistica 7.1 PL) according to the following linear model:

$Y_{i j k l m}=\mu+a_{i}+b_{j}+c_{k}+k_{l}+b c_{j k}+b k_{j l}+c k_{k l}+e_{i j k l m}$

where:

$Y_{i j k l m}$ - trait measured,

$\mu^{i k k l m}$ - overall mean,

a. $\quad$ - effect of $\operatorname{sex}(i=1,2)$,

$b_{j}^{i} \quad$ - effect of RYRl genotype $(j=C T, C C)$,

$c_{k} \quad$ - effect of $M Y O G$ genotype $(k=A A, A B)$;

$k_{l} \quad-$ effect of meatiness group $(l=\mathrm{I}, \mathrm{II})$;

$b c_{j k}$ - effect of interaction between RYRI and MYOG genotype;

$b k_{j l}^{j k}$ - effect of interaction between $R Y R l$ genotype and meatiness group;

$c k_{k l}^{j l}$ - effect of interaction between $M Y O G$ genotype and meatiness group;

$e_{i j k l m}-$ random error.

Detailed comparison of mean least squares (LSQ) for the analysed RYR1 and MYOG genotypes and meatiness group was done using Tukey test.

\section{Results and Discussion}

Two alleles, $C$ and $T$, were identified in the analysed pigs that determined the occurrence of two genotypes, $C T$ and $C C$, in locus RYRI (Table 1). The frequency of the $C$ allele was 0.65 , whereas that of the $T$ allele was 0.35 . Based on the analysis of genotypes in locus

Table 1. Frequency of RYRI and MYOG genotypes and allele in pigs

\begin{tabular}{|l|l|l|l|l|l|l|l|l|}
\hline \multirow{2}{*}{} & \multicolumn{2}{|c|}{ RYR1 } & \multicolumn{2}{c|}{$M Y O G$} & \multicolumn{4}{c|}{ Allele } \\
\cline { 2 - 10 } & CT & CC & AA & AB & C & T & A & B \\
\hline Number & 78 & 32 & 91 & 19 & & & & \\
\hline Frequency (\%) & 70.9 & 29.1 & 82.7 & 17.3 & 0.65 & 0.35 & 0.91 & 0.09 \\
\hline
\end{tabular}


Table 2. The LSQ means and their standard deviations (SD) of analyzed traits and relationship between genotypes at the loci $M Y O G$ and $R Y R 1$ and meatiness for slaughter value of carcass and basic chemical composition of meat in pigs

\begin{tabular}{|c|c|c|c|c|c|c|c|}
\hline \multirow[b]{2}{*}{ Traits } & \multirow[b]{2}{*}{ LSQ and SD } & \multicolumn{3}{|c|}{ Significance of influence of the factor } & \multicolumn{3}{|c|}{ Significance of influence of interaction } \\
\hline & & Meatiness & RYRI & $M Y O G$ & $\begin{array}{c}\text { Meatiness } \times \\
\text { RYRl }\end{array}$ & $\begin{array}{c}\text { Meatiness } \times \\
\text { MYOG }\end{array}$ & $R Y R I \times M Y O G$ \\
\hline $\begin{array}{l}\text { Lean content of } \\
\text { carcass }(\%)\end{array}$ & $53.57 \pm 3.11$ & $* *$ & ns & ns & ns & ns & ns \\
\hline $\begin{array}{l}\text { Mean backfat thickness } \\
\text { from } 5 \text { measurements }(\mathrm{cm})\end{array}$ & $2.38 \pm 0.37$ & $* *$ & ns & ns & $*$ & ns & ns \\
\hline Loin eye area $\left(\mathrm{cm}^{2}\right)$ & $45.87 \pm 5.52$ & $* *$ & ns & ns & ns & ns & ns \\
\hline Crude protein $(\%)$ & $23.50 \pm 0.67$ & ns & $\mathrm{ns}$ & ns & ns & ns & ns \\
\hline Intramuscular fat (\%) & $2.56 \pm 0.81$ & ns & ns & ns & $*$ & ns & ns \\
\hline Ash $(\%)$ & $1.16 \pm 0.12$ & ns & ns & ns & ns & ns & ns \\
\hline Dry matter $(\%)$ & $26.39 \pm 0.76$ & ns & ns & ns & ns & ns & ns \\
\hline
\end{tabular}

* - significant at $p \leq 0.05 ; * *$ - significant at $p \leq 0.01$; ns - not significant

Table 3. The LSQ means and their standard deviations (SD) of analyzed traits and relationship between genotypes at the loci MYOG and RYRI and meatiness for meat quality traits in pigs

\begin{tabular}{|c|c|c|c|c|c|c|c|}
\hline \multirow[b]{2}{*}{ Traits } & \multirow[b]{2}{*}{ LSQ and SD } & \multicolumn{3}{|c|}{ Significance of influence of the factor } & \multicolumn{3}{|c|}{ Significance of influence of interaction } \\
\hline & & Meatiness & RYRI & $M Y O G$ & $\begin{array}{c}\text { Meatiness } \times \\
R Y R I\end{array}$ & $\begin{array}{c}\text { Meatiness } \times \\
\text { MYOG }\end{array}$ & $R Y R I \times M Y O G$ \\
\hline $\mathrm{pH}_{1}$ & $6.22 \pm 0.34$ & ns & $*$ & ns & ns & ns & ns \\
\hline $\mathrm{pH}_{24}$ & $5.43 \pm 0.09$ & ns & ns & ns & ns & ns & ns \\
\hline $\mathrm{pH}_{48}$ & $5.39 \pm 0.08$ & ns & ns & ns & ns & ns & ns \\
\hline Meat lightness $\left(\mathrm{L}^{*}\right)$ & $54.29 \pm 2.13$ & ns & $*$ & ns & ns & ns & ns \\
\hline Tenderness (N/kg) & $72.47 \pm 19.14$ & ns & ns & ns & ns & ns & ns \\
\hline Thermal drip (\%) & $29.77 \pm 2.75$ & ns & ** & ns & ns & ns & ns \\
\hline WHC $\left(\mathrm{cm}^{2}\right)$ & $5.98 \pm 1.25$ & $*$ & $* *$ & ns & ns & ns & ns \\
\hline Water-soluble protein (\%) & $9.19 \pm 1.08$ & ns & $* *$ & ns & ns & $*$ & ns \\
\hline
\end{tabular}

* - significant at $p \leq 0.05 ; * *$ - significant at $p \leq 0.01$; ns - not significant

$R Y R 1$, a higher percentage of heterozygous $C T$ individuals was found (70.9\%), and lower of the $C C$ homozygotes $(29.1 \%)$. The analysis of alleles in locus $M Y O G$ showed a higher frequency of the allele $A(0.91)$ and lower of the allele $B(0.09)$, which determined the occurrence of two genotypes, $A A$ and $A B$. The percentage of the $A A$ porkers was $82.7 \%$, whereas of the $A B$ it was $17.3 \%$.

The carcass meatiness ranges adopted in the present study $(\leq 54 \%$ and $>54 \%)$ significantly differentiated the analysed porker carcasses with respect to meatiness, backfat thickness and the loin muscle eye area $(P \leq 0.01)$, which is presented in Tables 2 and 4 . The analysis of meat quality and its basic chemical composition showed significant differences only in meat water-holding capacity (WHC), which was favourably higher in the carcasses with meatiness below 54\% $(P \leq 0.05)$. Krzęcio et al. (2005) showed a negative effect of higher carcass meatiness on meat quality. On the other hand, Rybarczyk et al. (2006) did not find any differences in meat quality and its chemical composition according to carcass meatiness level in their studies on pigs from sows of white breeds and Pietrain boars.

The results presented in Table 2 show that no significant differences were found in the analysed hybrid pigs in carcass slaughter value traits and meat basic chemical composition according to $R Y R l$ genotype ( $C T$ and $C C$ ), which is also confirmed by studies of other authors (Fisher et al. 2000; Kusec et al. 2005). However, no positive effect of the 
Table 4. The LSQ means and standard deviation (SD) of meat quality traits depending on meatiness level

\begin{tabular}{|l|r|r|}
\hline Traits & $\leq 54 \%, \mathrm{n}=61$ & $>54 \%, \mathrm{n}=49$ \\
\hline Lean content of carcass $(\%)$ & $51.36^{\mathrm{A}} \pm 2.09$ & $55.91^{\mathrm{B}} \pm 1.88$ \\
\hline $\begin{array}{l}\text { Mean backfat thickness } \\
\text { from 5 measurements }(\mathrm{cm})\end{array}$ & $2.56^{\mathrm{A}} \pm 0.32$ & $2.19^{\mathrm{B}} \pm 0.29$ \\
\hline Loin eye area $\left(\mathrm{cm}^{2}\right)$ & $43.13^{\mathrm{A}} \pm 4.35$ & $48.35^{\mathrm{B}} \pm 4.52$ \\
\hline WHC $\left(\mathrm{cm}^{2}\right)$ & $5.69^{\mathrm{a}} \pm 1.23$ & $6.21^{\mathrm{b}} \pm 1.24$ \\
\hline
\end{tabular}

a,b Mean values in rows marked by different letters differ significantly at $p \leq 0.05$

$\mathrm{A}, \mathrm{B}$ Mean values in rows marked by different letters differ significantly at $p \leq 0.01$

Table 5. The LSQ means and standard deviation (SD) of meat quality traits depending on $R Y R 1$ genotype

\begin{tabular}{|l|r|r|}
\hline Traits & $C T, \mathrm{n}=78$ & \multicolumn{1}{|c|}{$C, \mathrm{n}=32$} \\
\hline $\mathrm{pH}_{1}$ & $6.21^{\mathrm{a}} \pm 0.32$ & $6.36^{\mathrm{b}} \pm 0.25$ \\
\hline Meat brightness $\left(\mathrm{L}^{*}\right)$ & $54.34^{\mathrm{a}} \pm 1.94$ & $53.51^{\mathrm{b}} \pm 1.87$ \\
\hline Thermal drip (\%) & $30.17^{\mathrm{A}} \pm 2.67$ & $28.58^{\mathrm{B}} \pm 2.81$ \\
\hline WHC, $\mathrm{cm}^{2}$ & $6.23^{\mathrm{A}} \pm 1.18$ & $5.15^{\mathrm{B}} \pm 1.13$ \\
\hline Water-soluble protein $(\%)$ & $9.09^{\mathrm{A}} \pm 0.98$ & $9.76^{\mathrm{B}} \pm 0.99$ \\
\hline
\end{tabular}

a,b Mean values in rows marked by different letters differ significantly at $p \leq 0.05$

${ }^{\mathrm{A}, \mathrm{B}}$ Mean values in rows marked by different letters differ significantly at $p \leq 0.01$ pigs in relation to meat quality traits, which was also observed by Krzęcio et al. (2005) in a study on pigs with $25 \%$ of Pietrain breed and by Rybarczyk et al. (2006) in a study on pigs with $50 \%$ of Pietrain breed in the genotype. In the present study, a significant interaction $(P \leq 0.05)$ was found between $R Y R I$ genotype and carcass meatiness range in mean backfat thickness from five measurements and intramuscular fat content. Among carcasses with meatiness up to $54 \%$, those of the pigs of $C C$ genotype were characterised by thinner backfat than those of the pigs of $C T$ genotype. On the other hand, fat content was higher in the pigs of $C C$ genotype than in those of $C C$ genotype among carcasses with meatiness above $54 \%$ (Table 6 ).

Important coding transcription genes play a crucial role in the development of skeletal muscles in which their expression occurs, and they belong to the MyoD family (Te Pas and Visscher 1994). In the present study, the effect of one gene of the MyoD family was analysed, i.e. the porcine myogenin $(M Y O G)$ gene, on carcass slaughter value and meat quality. The results did not reveal any significant differences between $A A$ and $A B$ genotypes at locus $M Y O G$ in carcass slaughter value, meat quality and its basic chemical

Table 6. Interaction (genotype $R Y R 1 \times$ carcass meatiness)

\begin{tabular}{|l|c|c|c|c|}
\hline \multirow{2}{*}{ Traits } & \multicolumn{2}{|c|}{$C T$} & \multicolumn{2}{c|}{$C C$} \\
\cline { 2 - 5 } & $\leq 54 \%, \mathrm{n}=40$ & $>54 \%, \mathrm{n}=38$ & $\leq 54 \%, \mathrm{n}=21$ & $>54 \%, \mathrm{n}=11$ \\
\hline $\begin{array}{l}\text { Mean backfat thickness from 5 } \\
\text { measurements (cm) }\end{array}$ & $2.65^{\mathrm{a}} \pm 0.33$ & $2.17^{\mathrm{b}} \pm 0.31$ & $2.41^{\mathrm{c}} \pm 0.24$ & $2.23^{\mathrm{bc}} \pm 0.25$ \\
\hline Intramuscular fat (\%) & $2.72^{\mathrm{ab}} \pm 0.81$ & $2.36^{\mathrm{a}} \pm 0.62$ & $2.58^{\mathrm{ab}} \pm 0.83$ & $3.15^{\mathrm{b}} \pm 1.12$ \\
\hline
\end{tabular}

Results in the table are given as LSQ mean and standard deviation.

a,b,c Mean values in rows marked by different letters differ significantly at $p \leq 0.05$ 
Table 7. Interaction (genotype $M Y O G \times$ carcass meatiness)

\begin{tabular}{|c|c|c|c|c|}
\hline \multirow{2}{*}{ Trait } & \multicolumn{2}{|c|}{$A A$} & \multicolumn{2}{c|}{$A B$} \\
\cline { 2 - 5 } & $\leq 54 \%, \mathrm{n}=50$ & $>54 \%, \mathrm{n}=41$ & $\leq 54 \%, \mathrm{n}=11$ & $>54 \%, \mathrm{n}=8$ \\
\hline Water-soluble protein $(\%)$ & $9.36^{\mathrm{ab}} \pm 1.09$ & $9.07^{\mathrm{a}} \pm 0.97$ & $9.28^{\mathrm{ab}} \pm 0.84$ & $10.05^{\mathrm{b}} \pm 0.96$ \\
\hline
\end{tabular}

Results in the table are given as LSQ mean and standard deviation.

${ }^{\mathrm{a}, \mathrm{b}}$ Mean values in rows marked by different letters differ significantly at $p \leq 0.05$

composition. However, a significant interaction $(P \leq 0.05)$ was found between $M Y O G$ genotype and carcass meatiness range for water-soluble protein content (Table 7). Among carcasses with meatiness above 54\%, meat of the pigs of $A B$ genotype was characterised by higher water-soluble protein content in relation to those of $A A$ genotype. In the study of Kapelański et al. (2005) on the stress susceptibility-gene ( $T$ )-free pigs, a higher colour lightness and higher water-soluble protein and ash contents were found in meat of the pigs of $A B$ genotype than of $A A$ genotype at locus $M Y O G$. This study also shows that animals of $B B$ genotype were characterised by more favourable meat quality in relation to those of $A A$ genotype in locus $M Y O G$ based on water-holding capacity, free drip, water-soluble protein content and water-holding capacity sensory evaluation. However, Kapelański et al. (2004) did not show any association of $M Y O G$ gene with most analysed meat quality traits in pigs after Pietrain boars, except for $\mathrm{pH}_{1}$ and meat colour. They found that the meat of the porkers of $B B$ genotype was characterised by higher $\mathrm{pH}_{\text {, }}$ and darker colour than in those of $A B$ genotype. Also in the study of Krzęcio et al. (2007b) on the stress susceptibility-gene (T)-free pigs with respect to the quality of meat of the LD muscle, a significant association was found of $M Y O G$ genotype with $\mathrm{pH}$ measured after $48 \mathrm{~h}$ post mortem, electrical conductance after $35 \mathrm{~min}, 3 \mathrm{~h}$ and $24 \mathrm{~h}$ post mortem and dry matter content in meat. They observed lower values of electrical conductance and dry matter content in meat of the pigs of $B B$ genotype in relation to those of $A B$ genotype. Furthermore, in the study on the same porkers carried out by Krzęcio et al. (2007a) a higher loin weight was determined by $B B$ genotype than that of ham by $A B$ genotype at locus $M Y O G$. Also Cieślak et al. (2002) found within the TORHYB programme an association of $M Y O G$ genotype with backfat thickness from several measurement points in pigs from Pietrain boars, which was thinner in animals of $A B$ genotype than in those of $B B$ genotype.

To recapitulate, the results lead to the conclusion that better pork quality of the $C C$ genotype was achieved compared to that of $C T$ genotype at locus $R Y R 1$, with similar carcass slaughter value and meat chemical composition, which confirms the need for further selection towards the elimination of the $T$ allele from the parent herds. No significant differences were found in carcass slaughter value and meat quality traits between $A A$ and $A B$ genotypes at locus $M Y O G$. No significant differences were also found between animals with lower and higher percentage of carcass meat content with respect to meat quality traits and its chemical composition, except for water-holding capacity (WHC) which was higher in pigs with meatiness $\leq 54 \%$ than in those with meatiness $>54 \%$. Furthermore, interaction was found between carcass meatiness range and RYRl genotype in the case of backfat thickness and intramuscular fat content, as well as between carcass meatiness range and $M Y O G$ genotype in relation to water-soluble protein content.

\section{References}

AOAC 1990: (Association of Official Analytical Chemists). Official Methods of Analysis, $15^{\text {th }}$ Ed., Washington DC

Biedermann G, Jatsch C, Peschke W, Lindner JP, Wittmann W 2000: Fattening and carcass performance and meat and fat quality of Pietrain pigs of different MHS-genotype and sex. I. Fattening and carcass performance and meat quality. Arch Tierz 43: 151-164

Cieślak D, Kurył J, Kapelański W, Pierzchała M, Grajewska S, Bocian M 2002: A relationship between genotypes at MYOG, MYF3 and MYF5 loci and carcass meat and fat deposition traits in pigs. Anim Sci Pap Rep 20: 77-92 
Commission International de I'Eclairage (CIE) 1976: Colorimetry. Official Recommendations of the International Commission on Illumination. Publication CIE, 1976; No. 15 (E-1.3.1). Bureau Central de la CIE, Paris, France

De Smet S, Pauwels H, Vervaeke I, De Bie S, Demeyer D, Callewier J, Eeckhout W 1996: Effect halothane genotype, breed, feed withdrawal and lairage on pork quality of Belgian slaughter pigs. J Anim Sci 74: 18541863

Fischer P, Mellett FD, Hoffman LC 2000: Halothane genotype and pork quality. 1. Carcass and meat quality charakteristics of three halothane genotypes. Meat Sci 54: 97-105

Fujii J, Otsu K, Zorzato F, De Leon S, Khana VK, Weiler JE, Obrien PJ, MacLennan DH 1991: Identification of a mutation in porcine ryanodine receptor associated with malignant hyperthermia. Sci 253: 448-451

Horák P, Urban T, Dvořák J 2004: Genetic variability of the CRC and MYF4 genes in genetic resource, Přeštice Black-Pied pigs. Arch Tierz 47: 231-238

Janik A, Pieszka M, Migdał W 2006: Effect of RYR1 genotype on carcass and meat quality in Polish Landrace pigs. Anim Sci Suppl 1: 70-71

Kapelański W, Grajewska S, Kurył J, Bocian M, Wyszyńska-Koko J, Urbański P 2005: Polymorphism in coding and non-coding regions of the $M y o D$ gene family and meat quality in pigs. Folia Biol, Suppl. 53: 45-49

Kapelański W, Grajewska S, Kurył J, Cieślak D, Bocian M, Hammermeister A 2004: Relationship between meat quality traits and polymorphism of MYF-3 and MYF-4 genes in crossbred pigs. Pol J Food Nutr Sci 13/54: 379-382

Koćwin-Podsiadła M, Kurył J 2003: The effect of interaction between genotypes at loci CAST, RYR1 and RN on pig carcass quality and pork traits - a review. Anim Sci Pap Rep 21, Suppl.: 61-75

Koćwin-Podsiadła M, Kurył J, Krzęcio E, Zybert A, Przybylski W 2003: The interaction between calpastatin and RYR1 genes for some pork quality traits. Meat Sci 65: 731-735

Kotik T 1974: Protein content in water extracts of meat as an index of its quality. Rocz Inst Przem Mięs 12: 47-52 [in Polish, English abstract]

Krzęcio E, Koćwin-Podsiadła M, Kurył J, Zybert A, Sieczkowska H, Antosik K 2007a: The effect of genotypes at loci CAST/MspI (calpastatin) and MYOG (myogenin) and their interaction on selected productive traits of porkers free of gene $R Y R 1^{T}$. I. Muscling and morphological composition of carcass. Anim Sci Pap Rep 25: 5-16

Krzęcio E, Koćwin-Podsiadła M, Kurył J, Zybert A, Sieczkowska H, Antosik K 2007b: The effect of genotypes at loci CAST/MspI (calpastatin) and MYOG (myogenin) and their interaction on selected productive traits of porkers free of gene $R Y R I^{T}$. II. Meat quality. Anim Sci Pap Rep 25: 17-24

Krzęcio E, Kurył J, Koćwin-Podsiadła M, Monin G 2005: Association of calpastatin (CAST/MspI) polymorphism with meat quality parameters of fatteners and its interaction with RYR1 genotypes. J Anim Breed Genet 122: 251-258

Kurył J., Kapelański W, Cieślak D, Pierzchała M, Grajewska S, Bocian M 2002: Are polymorphisms in noncoding regions of porcine $M y o D$ genes suitable for predicting meat and fat deposition in the carcass? Anim Sci Pap Rep 20, 245-254

Kusec G, Baulain U, Henning M, Köhler P, Kallweit E 2005: Fattening, carcass and meat quality traits of hybrid pigs as influenced by MHS genotype and feeding systems. Arch Tierz 48: 40-49

Oliver MA, Gispert M, Diestre A 1993: The effects of breed and halothane sensitivity on pig meat quality. Meat Sci 35: 105-118

Pohja MS, Niinivaara FP 1957: Die Bestimmung der Wasserbindung des Fleisches mittels der Konstantdrückmethode. Fleischwirtschaft 9: 193-195

Różycki M 1996: Pig evaluation rules in Polish Slaughter Pig Testing Stations. In: Situation in pig breeding and results of pig evaluation in 1995. Published by the National Research Institute of Animal Production, Balice: 69-82 [In Polish]

Rybarczyk A, Kmieć M, Szaruga R, Lepczyński A, Natalczyk-Szymkowska W 2006: The effect of RYR1 gene polymorphism and meat content of carcass on meat quality in crossbred Pietrain porkers. Anim Sci Pap Rep 24, Suppl.: 221-228

Soumillion A, Erkens JHF, Lenstra JA, Rettenberger G, Te Pas MFW 1997: Genetic variation in the porcine myogenin gene locus. Mamm Gen 8: 564-568

Te Pas MFW, Visscher AH 1994: Genetic regulation of meat production at embryonic muscle formation - a review. J Anim Breed Genet 111: 404-412

Urbański P, Kłosowska D, Kapelański W, Eliminowska-Wenda G, Pierzchała M, Walasik K, Bogucka J, Wyszyńska-Koko J, Kurył J 2007: A relationship between the polymorphism in the coding and 5' regions of the porcine $M y o D$ genes and microstructure traits of longissimus lumborum muscle. Anim Sci Pap Rep 25: 249-258

Walczak Z 1959: A laboratory method for the determination of jelly content in canned meat. Rocz Nauk Rol 74B-4: 619 [In Polish] 